УДК 656.2.11

\title{
СТРАТЕГІЧНЕ УПРАВЛІННЯ ЗАЛІЗНИЧНИМ ТРАНСПОРТОМ УКРАЇНИ
}

\author{
Чудомєх I.O., аспірант (УкрДУЗТ)
}

В статті доведена необхідність стратегічного управління залізничним транспортом Украӥни. 3'ясована суть поняття "стратегічне управління» та виділено базис для формування дієвої стратегії. Виконано дослідження внутрішнього середовища залізничного транспорту, виділені сильні та слабкі його сторони , серед яких головними є : критичний рівень зносу та низькі темпи оновлення рухомого складу ; низький рівень розвитку транспортно-логістичної інфраструктури; обмеженість у застосуванні прогресивних технологій перевезень; складність митних процедур і прикордонного контролю; частка ринку, яка належить залізницям, невпинно зменшується. Проведено аналіз зовнішнього середовища. Обгрунтовано, щзо транспортну стратегію слід спрямовати в периу чергу на ефективне використання транзитного потениіалу держави.

Ключові слова: стратегія , транспорт ,внутрішне та зовнішнє середовище, транспортний потенціал.

\section{СТРАТЕГИЧЕСКОЕ УПРАВЛЕНИЕ ЖЕЛЕЗНОДОРОЖНЫМ ТРАНСПОРТОМ УКРАИНЫ}

\author{
Чудомех И.А., аспирант (УкрГУЖТ)
}

В статье доказана необходимость стратегического управления железнодорожного транспорта Украины. Выяснена суть понятия «стратегическое управление» и выделен базис для формирования действенной стратегии. Выполнены исследования внутренней среды железнодорожного транспорта, выделенные сильные и слабые его стороны, среди которых главными являются: критический уровень износа и низкие темпь обновления подвижного состава; низкий уровень развития транспортно-логистической инфраструктуры; ограниченность в применении прогрессивных технологий перевозок; сложность таможенных процедур и пограничного контроля; доля рынка, принадлежащчая железным дорогам, постоянно уменьшается. Проведен анализ внешней среды. Обосновано, что транспортную стратегию следует направить в первую очередь на эффективное использование транзитного потенциала государства.

Ключевые слова: стратегия, транспорт, внутренняя и внешняя среда, транспортый потенциал.

\section{STRATEGIC MANAGEMENT OF RAILWAY TRANSPORT OF UKRAINE}

\section{Chudomeh I.A., a graduate student (UkrSU of RT)}

The article proves the necessity of strategic management of Railway Transport of Ukraine. Clarified the essence of the concept of "strategic management" and highlighted the basis for the formation of an effective strategy. The studies of the internal environment of rail transport allocated strengths and weaknesses of his hand, among which the main ones are: the critical level of wear and the low rate of renewal of rolling stock; low level of development of transport and logistics infrastructure; limitations in the application of advanced transportation technologies; complexity of customs procedures and border control; market share of railways is decreasing. The analysis of the external environment. It is proved that the transport strategy should spryamovaty primarily on the effective use of transit potential of the state.

Keywords: strategy, transport, internal and external environment, transport capacity. 
Постановка проблеми. Процеси глобалізації, зміни традиційних світових господарських зв'язків ставлять перед Україною завдання раціонального використання потенціалу свого унікального економікогеографічного положення, a ефективне використання транспортного потенціалу залізничного транспорту країни дозволить отримати економічний ефект від участі в міжнародних транспортних перевезеннях.

Однак, нестабільність зовнішнього середовища та загострення проблем $\mathrm{y}$ внутрішньому середовищі ускладнюють процес ефективного функціонування $\mathrm{i}$ розвитку транспортного потенціалу залізниць України, що викликає необхідність стратегічного управління ним.

Аналіз досліджень та публікацій. Концептуальні аспекти стратегічного управління представлені в працях О.С. Виханського [1], И.Ансоффа [2], Б.М. Шифріна [3], В.Л. Диканя, В.О. Зубенко, О.В. Маковоз, І.В.Токмакової, О.В. Шраменко [4] та ін.

На сьогодні тема дослідження теоретичних основ розвитку та управління транспортно-транзитним потенціалом України досить популярна, ій присвячена ціла низка праць за авторством: О. Чернеги, В. Белозубенко, А. Расторгуєва [5], С. Пирожкова, Д. Прейгера, I. Малярчука [6], Т. Блудової [7], Є. Жукова [8], М. Макаренко, М. Цвєтова [9] та ін.

Підходи щодо розвитку транспортного потенціалу залізниць України представлені і в існуючих програмних документах: Концепція розвитку транспортно-дорожнього комплексу України на середньостроковий період до 2020 року [10], Комплексна програма затвердження України як транзитної держави в 2002-2010 роках [11] та ін.

Виділення невирішених частин загальної проблеми. Аналіз теоретичних напрацювань 3 даної проблематики свідчить про високу зацікавленість вчених, особливу увагу приділено питанням: сучасний стан транспортного потенціалу України, проблеми та перспективи розвитку транспортної інфраструктури, формування транзитної привабливості країни. Разом 3 тим явно необхідні нові пропозиції, що дозволять добитися високих економічних результатів.

Мета статті. Тому, метою статті $\epsilon$ обгрунтування необхідності використання стратегічного управління для розвитку транспортного потенціалу залізниць України.

Виклад основного матеріалу дослідження. Стратегічне управління $\epsilon$ основою забезпечення ефективності функціонування будь-якого суб'єкта господарювання в сучасних нестабільних зовнішніх умовах. Базисом для формування дієвої стратегії розвитку транспортного потенціалу залізниць України $\epsilon$ аналіз можливостей та загроз зовнішнього середовища, а також сильних і слабких сторін внутрішнього середовища вітчизняного залізничного транспорту.

Дослідження внутрішнього середовища показало, що спостерігається:

a) критичний рівень зносу та низькі темпи оновлення рухомого складу (табл. 1).

Табличя 1

Показники зносу та оновлення рухомого складу залізниць Украӥни [12]

\begin{tabular}{|c|c|c|c|c|c|c|}
\hline \multirow{3}{*}{$\begin{array}{c}\text { Найменування } \\
\text { тягового } \\
\text { рухомого складу }\end{array}$} & \multicolumn{3}{|c|}{ Термін експлуатації } & \multicolumn{3}{|c|}{$\begin{array}{c}\text { Фактичне середньорічне } \\
\text { оновлення, од. }\end{array}$} \\
\hline & \multirow{2}{*}{ Нормативний } & \multicolumn{2}{|c|}{ Рівень спрацювання, \% } & \multirow{2}{*}{$\begin{array}{l}1987- \\
1990\end{array}$} & \multirow{2}{*}{$\begin{array}{l}1992- \\
2000\end{array}$} & \multirow{2}{*}{$\begin{array}{l}2001 \\
2012\end{array}$} \\
\hline & & $\begin{array}{c}\text { Ha 01.01. } \\
1990 \mathrm{p} .\end{array}$ & $\begin{array}{l}\text { Ha } 01.01 . \\
2014 \mathrm{p} .\end{array}$ & & & \\
\hline Тепловози & 20 & 58,3 & 93 & 162 & 4,5 & 0,3 \\
\hline Електровози & 30 & 59,3 & 89 & 70 & 3,7 & 8,1 \\
\hline $\begin{array}{c}\text { Секції } \\
\text { електропоїздів }\end{array}$ & 28 & 66,4 & 80 & 40 & 13,0 & 27,9 \\
\hline Дизель-поїзди & 20 & 62,0 & 97 & 9 & 0,5 & 3,1 \\
\hline
\end{tabular}

б) низький рівень розвитку транспортно-логістичної інфраструктури - за 2014 рік у вагонах із ознакою ДП «УТЛЦ» було перевезено 141,0 млн. тонн, що на $0,16 \%$ більше, ніж у 2012 році. Впродовж 2013 року укладено 1054 договори. За 2014 рік у вагонах із 
ознакою ДП «УТЛЦ» було перевезено 88,8 млн. тонн вантажів. За цей період укладено 472 нових договори у межах України та пролонговано 1397 договори. У транзитному сполученні за січень-вересень 2014 р. кількість договорів складає 99.

в) обмеженість у застосуванні прогресивних технологій перевезень - за січеньлистопад 2014 року залізниці України перевезли в складі контейнерних та комбінованих поїздів у всіх видах сполучень (імпорт, експорт, транзит та внутрішні перевезення) 79,6 тис. контейнерів (в ДФЕ - 20-футовому еквіваленті), що на 6,78\% більше ніж у 2013 році, коли було перевезено 74,5 тис. контейнерів в ДФЕ.

г) складність митних процедур i прикордонного контролю;

д) частка ринку, яка належить залізницям, невпинно зменшується . Основною причиною $є$ незадоволення цінами i якістю обслуговування на залізничному транспорті, незважаючи на приклади впровадження деяких нових послуг, які дозволяють сподіватися на краще. Відчувається, що залізничний транспорт не реагує на зміни ринкових умов або на попит споживачів так, як інші види транспорту.

При дослідженні зовнішнього середовища в першу чергу слід звернути увагу на той факт, що Україна - транзитна держава, іiі географічне положення на євразійському просторі $\epsilon$ унікальним, а потужний транспортний комплекс дозволяє забезпечувати зростаючі сьогодні транспортні потоки вантажів у напрямках Європа-Азія і Балтика-Чорне море.

Однак, обсяги транзитних вантажів, за даними Держкомстату за останні роки істотно скоротилися, не стане винятком і поточний рік. Спад транзитних вантажопотоків далі відбувається на фоні збереження або несуттєвого зростання загальних обсягів перевезень в залізничній і портовій галузях. Це говорить про те, що такі показники не варто списувати на кризові тенденції економіки в цілому. Зараз вони швидше можуть тільки стримувати зростання української економіки, ніж пояснити такий серйозний спад $\mathrm{y}$ перевезеннях.

Велика кількість зовнішніх та внутрішніх факторів впливають на даний перебіг подій. Виявити та визначити їх вплив $€$ головною необхідністю при розробці дієвої стратегії розвитку транспортного потенціалу України.
В першу чергу, для пошуку причин зниження транзитних потоків через Україну необхідно досліджувати коридори транспортування вантажів по різних маршрутах використовуючи при цьому основні критерії, які безпосередньо впливають на обсяг транзиту (час, вартість, надійність та безпека вантажу) i виявити вузькі місця, які негативно позначаються на транзитні потоки.

Відповідно, це дозволить визначити, які маршрути є більш привабливими, а які навпаки і в чому полягають причини цього та розробити заходи з подолання їх.

Наступним основним чинником, що впливає на розмір транзиту в Україні, як зазначалось вище, є недосконалість процедури проходження кордону. Україна, як і будь-яка інша країна, потребує подальшої розробки та впровадження прозорих процедур, оскільки це $\epsilon$ одним 3 головних факторів, що впливають на рішення вантажовласників. Вони повинні мати чітке уявлення, які документи потрібні на кордоні, як виглядає процедура, і скільки це буде коштувати. Все це впливає на привабливість України як транзитера.

Тим не менш, Україна виглядає не так вже погано в цьому відношенні, але все ж потребує поліпшення, щоб досягти таких результатів, як Західна Європа. Набагато гірші справи 3 цим питанням в Середній Азії, тому Україні необхідно користуватися даними перевагою для залучення транзитних вантажів.

Однак слід розглядати й інші фактори, для визначення причин зниження обсягу транзиту. Одним із головних напрямків пошуку забезпечення ефективного використання транзитного потенціалу України $\epsilon$ розгляд держави як складової частини окремо взятого транспортного коридору, тобто розвиток транзитного потенціалу напряму залежить від країн, що $є$ партнерами нашої держави по певному транспортному коридору.

Так, наприклад, Україна $є$ частиною коридору TRACECA, що включає в себе близько 12 країн. Це є однією з причин ії більш низької привабливості, яка витікає з відсутності гармонізованого документообігу і процедур на деяких пунктах перетину кордонів. Адже для того, щоб перевезти вантаж, потрібно неодноразово перетинати кордон і переплисти через два моря - Чорне і Каспійське. Всі ці фактори змушують компанії сумніватися в доцільності використання цього шляху для 
перевезення товарів між Європою і Китаєм. Якщо ж відправляти вантаж через Росію, то в цьому випадку потрібно буде перетнути кордон лише в декількох місцях - самої Росії, Білорусії і Казахстані, - які вже працюють над уніфікацією своїх процедур, і це значно спрощує транзит. Зараз TRACECA робить все можливе зі свого боку для уніфікації процедур, оскільки Україна в разі співпраці з усіма партнерами, такими як ЄC, Росія і Кавказ, могла б бути ідеальним транзитером.

Також якщо виконати оцінку різних варіантів маршруту транзиту (перший 3 них проходить територією Білорусі, Російської Федерації та Казахстану; другий лежить через Україну, Грузію, Азербайджан, Узбекистан, Киргизстан; третій шлях передбачає транспортування вантажів через такі країни, як Туреччина, Іран, Туркменістан, Таджикистан, Киргизстан), то найбільш привабливим для транзиту, за розрахунками головного транспортного експерта проекту TRACECA IDEA, буде перший варіант, який дозволяє вантажовласникам скорочувати витрати i економити час. Інші ж програють йому за всіма показниками. В основному це викликано затримкою на прикордонних пунктах пропуску $\mathrm{i}$ недостатньо прозорими процедурами.

Таким чином, використання транзитного потенціалу залізничного транспорту України більшою мірою залежить і від держав-партнерів по транспортному коридору.

Висновок. Україна володіє величезним транзитним потенціалом, який розкриється повною мірою у разі правильного використання і розуміння впливу його розвитку.

Для цього в Україні незабаром повинна з'явиться чітка позиція щодо транспортної стратегії. Це непросте завдання, що вимагає стратегічного управління і чималих зусиль, а також здатність прогнозувати вплив різних сценаріїв.

Тільки постійний моніторинг всіх зовнішніх i внутрішніх факторів, що безпосередньо впливають на транзитний потенціал держави, і побудова на цій основі стратегій, а також їх коригування у разі необхідності дозволить Україні досягти високих результатів у реалізації транзитного потенціалу.

\section{СПИСОК ЛІТЕРАТУРИ}

1. Виханский О. С. Стратегическое управление : учебник. / О. С. Виханский. - 2-е изд., перераб. и доп. - М. : Гардарики, 2005.- 169 с.

2. Ансофф И. Стратегическое управление / И. Ансофф ; пер. с англ. - М.: Экономика, 1989.$358 \mathrm{c}$.

3. Шифрин М.Б. Стратегический менеджмент : учеб. пособие / М.Б. Шифрин. ЧПб: Питер, 2009.-240 с.

4. Дикань В.Л. Стратегічне управління : навч.посіб./ В.Л.Дикань, В.О.Зубенко, О.В. Маковоз, І.В. Токмакова, О.В.Шраменко. - К: «Центр учбової літератури», 2013. -272с.

5. Чернега О.Б. Основные структурные особенности реализации транспортно-транзитного потенциала Украины /О.Б. Чернега, В.С. Белозубенко, А.С. Расторгуев// Вісник Хмельницького національного університету. Сер.: Економ. науки. Т. 3. - Хмельницький: ХНУ, 2008. - №3. - С. 101-106.

6. Пирожков С. Проблемы реализации транзитного потенциала Украины в контексте расширения ЕС и формирования ЕЭП /C. Пирожков, Д. Прейгер, И. Малярчук // Экономика Украины. - 2005. - №3. - С. 4-19.

7. Блудова Т. Глобализация транспортной системы и понятие «транзитный потенциал страны» /Т. Блудова// Экономика Украины. - 2006. - №10. - C. 73-78.

8. Жуков Е. Концептуальные научные основы государственной транспортной политики /Е. Жуков// Международная экономика. - 2006. №1. - С. 66-76.

9. Макаренко М. Транспортний сектор економіки України: тенденції та проблеми розвитку /М. Макаренко, М. Цвєтов// Економіст. 2007. - №6. - C. 24-27.

10. Концепція розвитку транспортнодорожнього комплексу України на середньостроковий період та до 2020 року //Офіційний сайт Міністерства транспорту i зв'язку України //www.mtu.ua.

11. Комплексна програма утвердження України як транзитної держави у 2002-2010 роках //Офіційний сайт Міністерства транспорту i зв'язку України // www.mtu.ua.

12. Офіційний сайт Державної адміністрації залізничного транспорту України [Електронний ресурс]: Режим доступа: http://uz.gov.ua/.

Рецензент д.е.н., професор УкрДУЗТ Компанієиь В.В. Експерт редакційної колехії к.е.н., доцент УкрДУЗТ Зубенко В.О. 